\title{
The Supply of Clean Water and the Problems in Benjeng Sub-District, Gresik, Indonesia
}

\author{
Esthi Kusdarini ${ }^{1}$, Suyadi ${ }^{2}$, Bagyo Yanuwiadi ${ }^{3}$, Lukman Hakim $^{4}$ \\ \{suyadi@ub.ac.id²\} \\ Universitas Brawijaya, Indonesia ${ }^{1,2,3,4}$
}

\begin{abstract}
Clean water is vital needs for life. Societies, in six villages in Benjeng SubDistrict, Gresik, Indonesia, were difficult to obtain clean water moreover in dry season. Therefore, the aims of this study are getting the depiction about the availability of clean water and the problem in the location of the research. This study was conducted by survey, laboratories analysis, and interview. The researchers conducted the survey in several locations of water resources. The researchers interviewed government officials and the society in these areas of the study. The research result shows that the society use lake water and water resource as clean water which is used for their needs. The main problem which is faced by the society is the availability of clean water that has not been full filled in dry season. Generally, well-water is available in year-round but, well-water sources are only found in few research locations. There are less than $30 \%$ who could consume well-water from the total of society in each village. Then, lake water is not almost available in summer season, especially in long summer. The problem is not only water quantity but also water quality which has not met the requirement of water quality. It was showed from several parameters in physics, chemistry and biology. Those all parameters are exceed the maximum limit of clean water standard based on Regulation of the Minister of Health of the Republic of Indonesia Number 32 of 2017. TDS is a parameter which has not met the parameters which have not met the requirements were TDS, turbidity, color, surfactant, organic matter, E. coli, and total coliform. As consequently, well-water and lake water are needed to treat before the society consumes that water.
\end{abstract}

Keywords: Clean Water, Benjeng, Gresik, Well-Water, Lake Water.

\section{Introduction}

Human needs clean water to fulfill their sanitation hygiene, such as bathing, toothbrushes, washing food and utensils, clothing and drinking. The requirements of clean water are regulated in the Regulation of the Minister of Health of the Republic of Indonesia Number 32 of 2017. Clean water is a component to keep human survival and each person needs 36.225 liters/day/person [1]. Relating to water supply, there are not all of regions could provide water quantities which meet with all of the people needs. Hispanic communities in the United States experience lack of water due to climate change [2]. In addition to adequate clean water, water quality also becomes important issue. The societies in several places doubt water quality which they consume, like in the Inuit Society in Northern Canada [3]. People should know the water quality which they consume. Society's perception is different with the fact of water quality and it causes inappropriate water treatment before the society consume it [4][5]. 
Society's perception to water quality which they consume affects household scale water treatment by the society [6].

The administrative areas in Benjeng are divided into 23 villages and six villages of Benjeng Areas have difficulty get clean water in the summer. Those villages are Metatu, Jatirembe, Jogodalu, Klampok, Sirnoboyo and Kalipadang Villages. Besides water availability in societies' villages, they also complained water quality. Based on clean water regulated, there are few parameters requirements; physics, chemistry and biology. The society uses clean water sources which pottentially contain contaminants and it endanger the health of living things that consume them [7][8]. Therefore, it is very important to identify the clean water parameters which are used by the society in these areas. Identifying the parameters of clean water was very important to determine the right processing method [6]. Researchers can conduct several methods to increase water quality, such as filtration, coagulation flocculation, ion exchangers, reverse osmosis, adsorption, and membranes [9][10][11][12][13][14][15]. In research locations, the selection of water treatment method to treat clear water is appropriate with parameter content but it has not meet requirement of clean water. Relating to water availability and water quality, several researchers have conducted this research.

Nanhidayah and Purnomo explained that the availability of clean water for the people of Metatu Village and Kalipadang Village was still limited. The main water source in Metatu Village is water lake and the main water source in Kalipadang village is well-water [16]. This research was explaining clean water availability two villages; Metatu and Kalipadang Village, but this research has not been able to explain clean water availability in six villages that have problems with limited clean water. Nanhidayah and Purnomo also explained that lake water has clear color, hard, organic matter content and the total coliform were quite high, but it has not explained the parameter levels. Because of it, it was really interesting to conduct further research about clean water availability in six villages that have limited clean water supply. In addition, the content of water contaminants and their levels are also important and interesting to learn since water is a vital requirement for humans.

\section{Methods}

\subsection{Location of Research and Survey}

This research was conducted in six villages in Benjeng Sub-District, Gresik, Indonesia on August 2018 until January 2019. Figure 1 presents research location. Survey activities include observation of water sources location, interview the related stakeholders, and take water samples. The related stakeholders refer to employees of public works in the field of clean water, sub-district employees, village officials, administrators of the Drinking Water Users Association and the Community.

\subsection{Taking Water Samples}

The aims of taking water samples were to know the physical, chemical and biological characteristics of the water which is used by the society. In this study, the researchers took six water samples, such as 3 lake water samples and 3 well-water samples. Those three lake water samples were T1 sample: taken from Metatu Lake (coordinate point $\mathrm{E}=112^{\circ} 29^{\prime} 55.49$ "and $\mathrm{S}$ $\left.=07^{\circ} 13^{\prime} 05.54 "\right)$, T2 sample: Jatirembe Lake (coordinate point $\mathrm{E}=112^{\circ} 30^{\prime} 21.73$ "and $\mathrm{S}=$ $07^{\circ} 11$ ' 24.73 "), and T3 sample: Paras Lake, Sinorboyo (coordinate points E = 112²9'44.93" 
and $\left.\mathrm{S}=07^{\circ} 15^{\prime} 13.46^{\prime \prime}\right)$. While, three well-water samples, $\mathrm{S} 1$ sample was taken from a bore well with a depth of $50 \mathrm{~m}$ in Jogodalu Village (coordinate point E $=112^{\circ} 29^{\prime} 40.78$ "and $\mathrm{S}=$ $\left.07^{\circ} 12^{\prime} 44.34^{\prime \prime}\right)$, S2 sample was from $100 \mathrm{~m}$ depth well in Klampok Village (coordinate points E $=112^{\circ} 35^{\prime} 19.94$ "and $\mathrm{S}=07^{\circ} 06^{\prime} 28.94^{\prime \prime}$ ) and sample S3 was from wells 8m deep in Kalipadang Village (coordinate points $\mathrm{E}=112^{\circ} 28^{\prime} 53.38$ "and $\left.\mathrm{S}=07^{\circ} 15^{\prime} 24.66^{\prime \prime}\right)$.

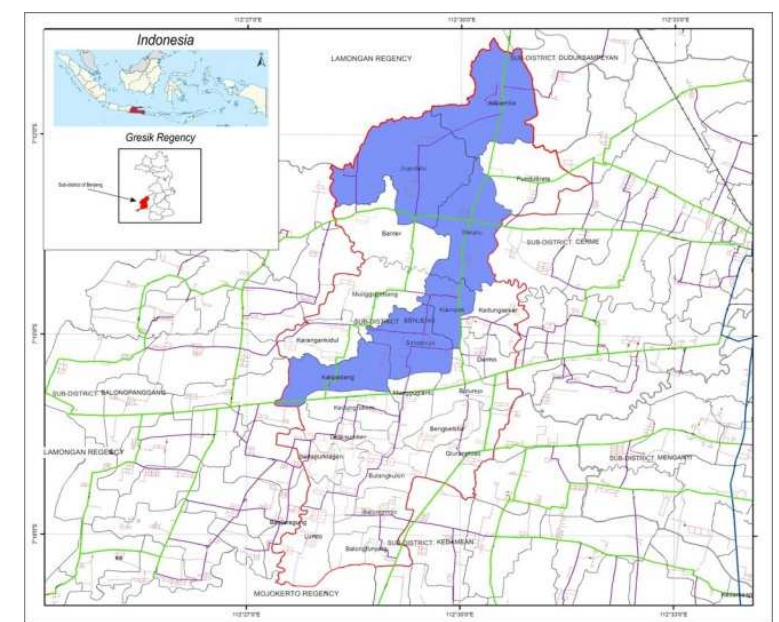

Fig. 1. Location of Metatu, Jatirembe, Jogodalu, Klampok, Sirnoboyo and Kalipadang Villages (blue).

\subsection{Analysis of Clean Water Parameters}

Water samples analysis include 18 clean water parameters based on Minister of Health Regulation of the Republic of Indonesia number 32 of 2017, namely six physical parameters, 10 chemical parameters and 2 biological parameters. Physical parameters include smell (SNI 01-3554-2006), taste (SNI 06-3554-2006), temperature (SNI 06-6989.23-2005), TDS (SNI 066989.27-2005), turbidity (SNI 06-6989.25 -2005), and colors (SNI 6989.80: 2011). Chemical parameters consist of pH (SNI 06-6989.11-2004), Fe (SNI 6989.4-2009), F (SNI 06-6989.292005), CaCO3 (SNI 06-6989.12-2004), Mn (SNI 6989.5-2009), nitrate (SNI 6989.79: 2011), nitrite (SNI 06-6989.9-2005), CN (EI 36,177 (Spectrophotometry)), surfactants (SNI 066989.51-2005) and total organic substances (SNI 06-6989.22-2004). Biological parameters were E. Coli (SNI ISO 9308-1: 2010) and total coliform (SNI ISO 9308-1: 2010).

\section{Result and Discussion}

\subsection{Supply of Clean Water}

The society uses lake water and well-water to meet clean water needs. Table 1 presents the number of lake in each village.

Table 1. Lakes at the research location

\begin{tabular}{cc} 
Village & Lake Numbers \\
\hline Metatu & 4
\end{tabular}




\begin{tabular}{cc} 
Jogodalu & 4 \\
Jatirembe & 2 \\
Klampok & 6 \\
Sirnoboyo & 3 \\
Kalipadang & 3 \\
\hline
\end{tabular}

Most of these lakes experience drought in summer while the wells are only found in small number in these areas. People can use well-water were less than $30 \%$ in each village because the difficulty of getting ground water was the cause of the community using well water. The society can obtain ground water after digging 8 meters or more from the depth of the soil because the soil was dominated by clay which has quite high impermeability to water [17]. Impermeability can cause of rainwater to be retained and it will difficult to seep into the soil and the water becomes groundwater source.

\subsection{Available Water Quality}

Clean water sources are lake water and well-water but both of these sources have different quality. The reader can read the data of availability of water quality in parameters of water samples which is presented in Table 2. Furthermore, clean water has several varying qualities, but generally, it has not met the requirements of clean water, especially for TDS, organic matter, E. coli and total coliform parameters.

Table 2. Physical, chemical and biological parameters of Lake $(\mathrm{T})$ and Well-Water (S) samples

\begin{tabular}{|c|c|c|c|c|c|c|c|c|}
\hline \multirow[t]{2}{*}{ Parameters } & \multicolumn{6}{|c|}{ Samples } & \multirow[b]{2}{*}{$\begin{array}{c}\text { Max } \\
\text { Limit** }\end{array}$} & \multirow[b]{2}{*}{ Unit } \\
\hline & T1 & T2 & T3 & S1 & S2 & S3 & & \\
\hline \multicolumn{9}{|l|}{ Physical } \\
\hline Smell & No Smell & No Smell & No Smell & No Smell & No Smell & No Smell & No Smell & - \\
\hline Taste & Normal & Normal & Normal & Normal & Normal & Normal & Normal & - \\
\hline Temperature & 25.3 & 25.2 & 24.9 & 25 & 25.1 & 24.9 & $\begin{array}{c}\text { Water } \\
\text { Temp. } \pm 3\end{array}$ & ${ }^{\circ} \mathrm{C}$ \\
\hline TDS & 893 & 288 & 378 & 835 & 2660 & 1109 & 1000 & $\mathrm{mg} / \mathrm{L}$ \\
\hline Turbidity & 32.5 & 28.9 & 13.7 & 3.01 & 1.14 & 0.77 & 25 & NTU \\
\hline Color & 63.3 & 92.6 & 8.8 & 0.4 & 59.1 & 0.4 & 50 & $\mathrm{Pt} / \mathrm{Co}$ \\
\hline \multicolumn{9}{|l|}{ Chemical } \\
\hline $\mathrm{pH}$ & 8.02 & 8.63 & 8.06 & 7.43 & 8.02 & 7.29 & $6.5-8.5$ & $\mathrm{pH}$ unit \\
\hline $\mathrm{Fe}$ & 0.12 & 0.13 & 0.09 & 0.06 & 0.12 & 0.03 & 1 & $\mathrm{mg} / \mathrm{L}$ \\
\hline $\mathrm{F}$ & 1.06 & 0.56 & 1.12 & 0.7 & 0.62 & 0.64 & 1.5 & $\mathrm{mg} / \mathrm{L}$ \\
\hline $\mathrm{CaCO}_{3}$ & 124 & 128 & 144 & 418 & 160 & 300 & 500 & $\mathrm{mg} / \mathrm{L}$ \\
\hline $\mathrm{Mn}$ & 0.01 & 0.01 & $<0.006$ & 0.11 & 0.07 & $<0.006$ & 0.5 & $\mathrm{mg} / \mathrm{L}$ \\
\hline Nitrate & 0.96 & 0.103 & $<0.04$ & 0.19 & $<0.04$ & 5.5 & 10 & $\mathrm{mg} / \mathrm{L}$ \\
\hline Nitrite & 0.019 & 0.01 & $<0.01$ & 0.027 & 0.19 & 0.047 & 1 & $\mathrm{mg} / \mathrm{L}$ \\
\hline $\mathrm{CN}$ & $<0.004$ & $<0.004$ & $<0.004$ & $<0.004$ & $<0.004$ & $<0.004$ & 0.1 & $\mathrm{mg} / \mathrm{L}$ \\
\hline Surfactant & $<0.05$ & 0.3 & 0.1 & $<0.05$ & 0.064 & 0.14 & 0.05 & $\mathrm{mg} / \mathrm{L}$ \\
\hline Organic Matter & 20.5 & 18 & $<4.3$ & 14.2 & 21.3 & $<4.3$ & 10 & $\mathrm{Mg} / \mathrm{L}$ \\
\hline \multicolumn{9}{|l|}{ Biology } \\
\hline E.Coli & 1 & 0 & 21 & 0 & 81 & 10 & 0 & $\begin{array}{l}\text { Col./100 } \\
\mathrm{mL}\end{array}$ \\
\hline T.coliform & 68 & 24 & 93 & 256 & 120 & 141 & 50 & $\begin{array}{l}\text { Col./100 } \\
\mathrm{mL}\end{array}$ \\
\hline
\end{tabular}

Source: Minister of Health of the Republic of Indonesia Number 32 of 2017.

Table 2 shows that lake water varies in quality, but generally do not meet clean water requirements, especially for turbidity, color, organic matter, E. coli and total coliform parameters. Furthermore, well water also varies in quality, but in general also does not meet 
clean water requirements, especially for the parameters of TDS, organic matter, E. coli and total coliform.

\subsection{Problems Faced by the Society}

The limited access to get clean water in summer is a problem which is faced by the society. Even though, the government had made 4 wells centrally but it was only a well centralized which has good quality to consume and use. The deep of centralized well is50 meters which is located in Jogodalu Village. In table 2, Jogodalu well-water sample (S1) has good physical parameters but the organic matter contain and total coliform are quite high. This fact prove that there was a mismatch between society's perception and the actual of water condition [6][18]. Centralized well-water in Klampok Village (S2 sample) has bad condition based on society's perception. This was accordance with the actual water parameters because TDS, color, organic matter, E.coli, and total coliform have high parameters. Bad perception made other society to be reluctant to use well-water during dry season. Similar condition is also happened in some communities around centralized well-water in Sirnoboyo and Kalipadang Villages who reluctant to use a kind of centralized well water to meet their clean water needs. The society must conduct water treatment to make well-water quality like Table 2 before they use it as their needs. Table 2 showed that all of water samples have not met the standard of clean water [19]. From that explanation, the researchers and the society knew that both lake water and well-water needed to be processed before the society use lake water and well-water for their daily life.

Coagulation of flocculation and filtration method can use to treat lake water [13], [15]. The researchers used these methods because water lake parameters have not met requirement of clean water, such as turbidity, color, organic matter, E. coli, and total coliform. Although the filtration and flocculation coagulation process are able to reduce contain of E.coli and total coliform, but if the content of biological pollutant is quite high, the researchers can add water disinfectants, namely calcium hypochlorite $\left(\mathrm{Ca}(\mathrm{ClO})_{2}\right)$. Both methods were effective enough if those methods apply to treat lake water and well-water which do not contain high total dissolve solid (TDS). Reverse osmosis and membranes can be used as processing methods to reduce high TDS (S2 samples) but these methods need more investment costs and more complicated than coagulation and filtration methods.

\section{Conclusion}

The society used lake water and well-water to meet their clean water needs which could only be met during rainy season. In dry season, clean water was only available from wellwater and few small lakes which still leaved their water. Generally, well-water was available throughout the year, but there were less than $30 \%$ from the total population for each village who could consume well-water. The cause was the society was difficult to find ground water sources in this area. Furthermore, centralized wells were made by local have bad water quality according to society' perception and actual condition. The result of laboratory analysis showed that the physical, chemical, and biological parameters of lake water and well-water have not met the requirements of clean water based on the Regulation of the Minister of Health of the Republic of Indonesia Number 32 of 2017. The use of lake water and well-water required treatment before both of water sources were consumed. Lake water and well-water which did not contain high TDS could be processed using filtration and flocculation coagulation 
methods. Well-water which contained high TDS could be processed using reverse osmosis and membrane methods.

\subsection{Acknowledgment}

This research was funded by the Education Fund Management Institute, Ministry of Finance of the Republic of Indonesia.

\section{References}

[1] Departemen Pekerjaan Umum Direktorat Jendral Cipta Karya Air Bersih, "Pedoman Teknis Penyediaan Air Bersih IKK Pedesaan.” Departemen Pekerjaan Umum, Jakarta, 1990.

[2] J. Kang, K. Grable, G. Hustvedt, and M. Ahn, "Sustainable water consumption: The perspective of Hispanic consumers," J. Environ. Psychol., vol. 50, pp. 94-103, 2017.

[3] C. J. Wright, J. M. Sargeant, V. L. Edge, J. D. Ford, K. Farahbakhsh, I. Shiwak, C. Flowers, A. C. Gordon, and S. L. Harper, "How are perceptions associated with water consumption in Canadian Inuit? A cross-sectional survey in Rigolet, Labrador," Sci. Total Environ., vol. 618, pp. 369-378, 2018.

[4] J. G. Lev^eque a and R. C. Burns, "A Structural Equation Modeling approach to water quality perceptions," J. Environ. Manage., vol. 197, pp. 440-447, 2017.

[5] B. Ochoo, J. Valcour, and A. Sarkar, "Association between perceptions of public drinking water quality and actual drinking water quality: A community-based exploratory study in Newfoundland (Canada)," Environ. Res., vol. 159, pp. 435-443, 2017.

[6] C. Prouty and Q. Zhang, "How do people's perceptions of water quality influence the life cycle environmental impacts of drinking water in Uganda?," Resour. Conserv. Recycl., vol. 109, pp. 24-33, 2016.

[7] M. V. Esteller, N. Kondratenko, J. L. Expósito, M. Medina, and M. A. Martin del Campo, "Hydrogeochemical characteristics of a volcanic-sedimentary aquifer with special emphasis on Fe and Mn content: A case study in Mexico," J. Geochemical Explor., vol. 180, pp. 113-126, 2017.

[8] T. S. Rini, A. Rachmansyah, A. W. Muhaimin, and S. Suyadi, "Participation of waste pickers in waste management: A case study at randegan landfill Mojokerto, Indonesia," World Appl. Sci. J., vol. 25, no. 7, pp. 1036-1043, 2013.

[9] A. Amini, Y. Kim, J. Z. Zhang, T. Boyer, and Q. Zhang, "Environmental and Economic Sustainability of Ion Exchange Drinking Water Treatment for Organics Removal," J. Clean. Prod., pp. 1-49, 2015.

[10] M. Nitsae, A. D. R. Madjid, L. Hakim, and A. Sabarudin, "Effect of Tripolyphosphate and Ethylene Glycol Diglicidyl Ether on Chitosan Beads for Cr (VI) Adsorption," Nat. B, vol. 3, no. 3, pp. 220-225, 2016.

[11] E. Kusdarini, A. Budianto, and D. Ghafarunnisa, "Produksi Karbon Aktif dari Batubara Bituminus dengan Aktivasi Tunggal H3PO4, Kombinasi H3PO4-NH4HCO3, dan Termal," Reaktor, vol. 17, no. 2, pp. 74-80, 2017.

[12] E. Kusdarini and A. Budianto, "Removal of Manganese from Well-Water on Pasuruan, East Java, Indonesia Using Fixed Bed Cation Exchanger and Prediction of Kinetics Adsorption," Indian J. Sci. Technol., vol. 11, no. 23, pp. 1-7, 2018.

[13] B. Ma, W. Xuea, C. Hua, H. Liud, J. Qua, and L. Li, "Characteristics of microplastic removal via coagulation and ultrafiltration during drinking water treatment," Chem. Eng. J., vol. 359, pp. 159-167, 2019.

[14] A. Budianto, E. Kusdarini, S. Effendi, and M. Aziz, "The Production of Activated Carbon from Indonesian Mangrove Charcoal," Mater. Sci. Eng., vol. 462, pp. 1-8, 2019.

[15] R. P. Freitas de Oliveira, Fernando Schneider, "Slow Sand Filtration for Biofouling Reduction 
in Seawater Desalination by Reverse Osmosis," Water Res., pp. 1-44, 2019.

[16] A. Nanhidayah and A. Purnomo, "Sistem Penyediaan Air Bersih Desa Metatu dan Desa Kalipadang Kecamatan Benjeng Kabupaten Gresik,” J. Tek. ITS, vol. 6, no. 2, pp. D159-D164, 2017.

[17] A. S. Braswella, R. J. Winstonb, and W. F. Hunt, "Hydrologic and water quality performance of permeable pavement with internal water storage over a clay soil in Durham, North Carolina," $J$. Environ. Manage., vol. 224, pp. 277-287, 2018.

[18] A. V. Kulinkina, J. D. Plummer, K. K. H. Chui, K. C. Kosinski, T. Adomako-Adjei, A. I. Egorov, and E. N. Naumova, "Physicochemical parameters affecting the perception of borehole water quality in Ghana," Int. J. Hyg. Environ. Health, vol. 220, no. 6, pp. 990-997, 2017.

[19] ministry of Health, Regulatory of Health Minister of Republic of Indonesia 32/2017. 2017, p. 31. 